\title{
PERBEDAAN LATIHAN NAIK TURUN TANGGA TUNGGAL (SATU TANGGA) DENGAN NAIK TURUN TANGGA JAMAK (ENAM TANGGA) TERHADAP KEMAMPUAN LARI SPRINT 60 METER SISWA KELAS V SD NEGERI 69 KOTA BENGKULU.
}

\author{
Fardede Pujiansyah Ismail \\ Universitas Bengkulu \\ fardede@gmail.com \\ Arwin \\ Universitas Bengkulu \\ Tono Sugihartono \\ Universitas Bengkulu
}

\begin{abstract}
Abstrak
Penelitian ini bertujuan untuk mengetahui perbedaan latihan naik turun tangga tunggal (satu tangga) dengan latihan naik turun tangga jamak (enam tangga) untuk menentukan latihan mana yang baik digunakan untuk meningkatkan kemampuan lari sprint 60 meter siswa kelas V SD 69 Kota Bengkulu. Jenis penelitian ini adalah penelitian kuantitatif dengan metode penelitian menggunakan Eksprimen kuasi. Sampel pada peneletian ini adalah siswa kelas $\mathrm{V}$ SD Negeri 69 Kota Bengkulu yang berjumlah 40 siswa. Hasil penelitian menunjukkan ada perbedaan yang signifikan antara tangga tunggal (satu tangga) dengan latihan naik turun tangga jamak (enam tangga) dengan t-hitung 2,278 dan t-tabel 2,101. Yang menunjukkan bahwa t-hitung lebih besar dari t-hitung maka terdapat perbedaan antara tangga tunggal (satu tangga) dengan latihan naik turun tangga jamak (enam tangga).
\end{abstract}

Kata kunci: latihan naik turun tangga tunggal, latihan naik turun tangga jamak, lari spirint 60 meter

\begin{abstract}
The aim of this research is to know the difference of down one staircase (one ladder) exercise with up and down stairs plot (six stairs) to determine which good exercise is used to improve sprint 60 meter ability of grade V SD 69 Bengkulu. The type of this research is quantitative research with research method using quasi expriment. The sample in this research is the students of class V SD Negeri 69 Kota Bengkulu which amounts to 40 students. The results showed that there was a significant difference between single ladder (one ladder) with practice of up and down stairs plural (six stairs) with t-count 2,278 and t-table 2,101. Which shows that $t$-count is greater than $t$-Caa11lount then there is a difference between single ladder (one ladder) with practice up and down stairs plural (six stairs).
\end{abstract}

Keywords: down stairs single exercise, up and down stairs plural exercise, spirint sprint 60 meters

PENDAHULUAN
Pendidikan Jasmani dan Kesehatan pada dasarnya merupakan bagian integral dari sistem pendidikan secara keseluruhan, 
bertujuan untuk mengembangkan aspek kesehatan, kebugaran jasmani, keterampilan berpikir kritis, stabilitas emosional, keterampilan sosial, penalaran dan tindakan moral melalui aktivitas jasmani dan olahraga. Pendidikan Jasmani dan Kesehatan sebagai pendidikan gerak dan pendidikan melalui gerak memiliki aspek-aspek gerak yang ingin dicapai. Adapun struktur materi Pendidikan Jasmani untuk TK sampai SD/MI kelas 3 SD meliputi kesadaran akan tubuh dan gerakan, kecakapan gerak dasar, gerakan ritmik, permainan, akuatik (olahraga di air bila memungkinkan), senam, kebugaran jasmani dan pembentukan sikap dan perilaku. Dan materi pembelajaran untuk SD/MI kelas 4 sampai 6 adalah aktivitas pembentukan tubuh, permainan dan modifikasi olahraga, kecakapan hidup di alam bebas, dan kecakapan hidup personal (kebugaran jasmani serta pembentukan sikap dan prilaku).

Seorang siswa yang ingin berprestasi harus memiliki kondisi fisik yang prima dan teknik yang baik. Apabila seorang siswa mempunyai kondisi fisik dan teknik yang baik maka untuk mencapai prestasi yang maksimal akan mudah terwujud. Akan tetapi, unsur fisik dan teknik saja tidak akan cukup untuk mencapai prestasi yang maksimal sebab prestasi yang dicapai para pelari pada umumnya ternyata harus didukung pula oleh aspek lain yang tidak kalah pentingnya, yakni aspek taktik, mental dan latihan. Mengenai pentingnya aspekaspek tersebut, Harsono (1988 : 60) mengemukakan bahwa "Ada empat aspek latihan yang perlu diperhatikan dan dilatih secara seksama oleh altet yaitu : (a) latihan fisik, (b) latihan teknik, (c) latihan taktik,dan (d) latihan mental".

Bermacam teknik dan metode latihan lari sprint pada olahraga atletik yang dapat diterapkan oleh guru Penjas orkes terhadap para siswa, salah satunya adalah dengan latihan naik turun tangga yang tujuanya tiada lain adalah untuk menambah kekuatan otot kaki agar mampu meningkatkan kempuan lari sprint. Menurut peneliti ada beberapa alasan latihan naik turun tangga dapat berpengaruh terhadap kemampuan lari sprint pada olahraga atletik, salah satunya adalah latihan naik turun bangku.

Berdasarkan hasil pengamatan pada saat melakukan magang 3 di SD Negeri 69 Kota Bengkulu kemampuan lari siswa belum maksimal, masalah yang ditemukan peneliti pada saat magang 3, kaki anak yang kurang bertenaga pada saat berlari, langkahnya kelihatan berat, singkronisasi antar gerak tangan dan kaki kurang stabil, posisi tulang punggung yang kurang pas, dan disebabkan lapangan yang kurang memadai, Oleh karena itu peneliti berinisiatif untuk melakukan latihan naik turun tangga tunggal (satu tangga) dengan naik turun tangga jamak (enam tangga). Untuk memecahkan masalah diatas peneliti berfikir latihan naik turun tangga tunggal (satu tangga) dan latihan naik turun tangga jamak (enam tangga) adalah solusi yang tepat.

Penelitian ini peneliti akan membandingkan hasil dari latihan naik turun tangga tunggal atau (satu tangga) dengan hasil latihan naik turun tangga jamak (enam tangga) terahadap kemampuan dan kecepatan waktu yang diperoleh pada saat melakukan lari sprint 60 meter. Hasil tersebut akan menunjukkan perbedaan yang signifikan dalam melakukan latihan. Melaui penelitian mampu mengetahui perbedaan antara latihan naik turun tangga tunggal dengan naik turun tangga jamak.

Berdasarkan latar belakang di atas peneliti tertarik untuk mengetahui perbedaan latihan naik turun tangga tunggal atau satu tangga dangan latihan naik turun tangga jamak dengan enam anak tangga di SD Negeri 69 Kota Bengkulu dengan judul penelitian "Perbedaan Latihan 
Naik Turun Tangga Tunggal (satu tangga) dengan Naik Turun Tangga Jamak (enam tangga) Terhadap Kemampuan Lari Sprint 60 Meter Siswa Kelas V SD Negeri 69 Kota Bengkulu. Berdasarkan pembatasan masalah diatas, maka rumusan masalah yang dalam penelitian ini adalah "Apakah ada perbedaan Latihan Naik Turun Tangga Tunggal (Satu tangga) Dengan Naik Turun Tangga Jamak (enam tangga) Terhadap Kemampuan Lari Sprint 60 Meter Siswa Kelas V SD Negeri 69 Kota Bengkulu?

\section{Kajian Teori}

Atletik juga dijelaskan Saputra. (2001:1) adalah: Atletik merupakan istilah yang sudah diahli bahasakan dari berbagai istilah sebelumnya. Sebenarnya, istilah Atletik berasal dari Bahasa yunani yaitu "Athlon" memiliki makna bertanding atau berlomba. Istilah Athlon hingga saat ini masih sering digunakan seperti yang kita dengar kata "Pentathlon" atau "Decathlon". Pentatlhon memiliki makna panca lomba, meliputi lima jenis lomba, sedangkan Decathlon adalah dasa lomba, meliputi 10 jenis lomba.

Atletik adalah aktifitas jasmani yang kompetitif atau dapat diadu berdasarkan gerak dasar manusia, yaitu seperti berjalan, berlari, melempar, dan melompat. Atletik seperti yang kita ketahui sekarang, dimulai sejak diadakan olympiade modern yang pertama kali diselenggarakan di kota Athena pada tahun 1896 dan sampai terbentuknya badan dunia federasi athletik amatir internasional tahun 1912. Atletik pertama kali diperkenalkan di Indonesia dengan sebutan Netherlands Indische Athletick Unie (NIAU) tanggal 12 Juli 1917 dan dalam perkembangannya terbentuk suatu organisasi yang bergerak dibidang atletik dengan nama Persatuan Atletik Seluruh Indonesia (PASI).

Atletik saat ini menjadi salah satu cabang olahraga yang cukup populer di kalangan masyarakat indonesia. Dengan lahirnya atlet-atlet nasional saat ini membuktikan bahwa cabang olahraga altetik cukup mendominasi perkembangan olahraga di Indonesia. Menurut Kamus Umum Bahasa Indonesia tulisan Purwadanninta (1996 :28) dalam Nanang (2012), kemampuan adalah kesanggupan, kecakapan, kekuatan, dan kekayaan. Kemampuan merupakan suatu kapasitas umum yang berkaitan dengan prestasi berbagai macam ketrampilan atau lebih (Yanuar Kiram, 1992:11). Dalam Kamus Besar Bahasa Indonesia (2002: 28), kemampuan memiliki kata dasar mampu yang berarti kuasa melakukan sesuatu, sanggup, atau dapat. Kemudian kemampuan adalah kesanggupan, kekuatan untuk melakukan sesuatu, berdasarkan apa yang dimilikinya."

Dengan melihat defenisi di atas kemampuan dapat diartikan bahwa sesuatu yang dimiliki dalam diri seseorang, kemudian seseorang dapat dan sasnggup untuk melakukan sesuatu. Dengan defmisi tersebut kemampuan lari adalah kesanggupan atau kecakapan seseorang dalam melakukan lari secara benar dan terstruktur sesuai kaidah lari yang ada; kesanggupan seseorang melakukan aktivitas lari dengan menempuh jarak tertentu dan dengan waktu yang sesingkat mungkin. Kemampuan lari dibagi menjadi 3 yaitu kemampuan start, lari, dan melakukan finish. Kemampuan lari menerapkan berbagai kecakapan dan ketrampilan teknik, fisik, dan psikis dalam melakukan lari.

\section{Lari Cepat (Sprint) 60 Meter}

Lari cepat (Sprint) dijelaskan Yudha M. Saputra (2001:39) adalah: Lari cepat (sprint) adalah suatu kemampuan yang ditandai proses memindahkan posisi tubuhnya, dari satu tempat ketempat yang lainnya secara cepat, melebihi gerak dasar pada keterampilan lari santai (jogging). Lari cepat (sprint) terdiri dari tiga jenis keterampilan yaitu, lari cepat, lari gawang dan lari estafet. 
Lari jarak pendek disebut juga dengan istilah sprint atau lari cepat. Sprint merupakan suatu perlombaan lari. Peserta berlari dengan kecepatan penuh sepanjang jarak yang harus ditempuh. Disebut dengan lari cepat karena jarak yang ditempuh adalah pendek atau dekat. Jadi, dalam nomor lari ini yang diutamakan adalah kecepatan yang maksimal mulai dari awal lari (start) sampai akhir lari (finish). Mengingat dalam lari ini yang diutamakan adalah kecepatan maka kekuatan fisik yang prima sangat diperlukan.

\section{Definisi Latihan}

Latihan sebagaimana dijelaskan dalam Apta Mylsidayu dan Febi Kurniawan (2015:47) adalah : Istilah latihan berasal dari kata bahasa inggris yang dapat mengandung beberapa makna seperti : practice, exercise, dan traning. Pengertian latihan yang berasal dari kata practice adalah aktivitas untuk meningkatkan keterampilan (kemahiran) berolahraga dengan menggunakan berbagai peralatan sesuai dengan tujuan dan kebutuhan cabang olaharaganya. Artinya, selama dalam kegiatan proses berlatih melatih agar dapat menguasai keterampilan gerak cabang olahraganya selalu dibantu dengan mengggunakan berbagai peralatan pendukung.

\section{Naik turun tangga tunggal}

Latihan naik turun bangku (tangga tunggal) merupakan tes kesegaran jasmani yang sederhana Menurut Agustina Utari (2007:35). Tes ini bertujuan untuk mengukur kesegaran jasmani untuk kerja otot dan kemampuannya pulih dari kerja. Caranya adalah dengan naik turun bangku terus menerus selama 5 menit dengan kecepatan 30 langkah menit. Selama 5 menit denyut jantung diukur dalam menit ke-1, menit ke-2 dan menit ke-3 yang menunjukan waktu pemulihan setelah latihan.

\section{Naik turun tangga jamak}

Olahraga naik turun tangga adalah salah satu jenis olahraga yang efektif membakar lemak, olahraga ini juga efektif untuk menguatkan jantung dan meningkatkan ketahanan tubuh. setiap menitnya, aktivitas naik tangga diperkirakan akan mengkonsumsi enegri (membakar kalori) sebanyak 8-11 kalori. Nilai ini merupakan nilai yang cukup tinggi jika dibandingkan dengan aktivitas olahraga dengan intensitas sedang seperti tenis, badminton, sepak bola dan juga basket, yang mengonsumsi energi sebanyak 7-9 kalori permenit. (Anggraeni, 2013).

Pengertian latihan menurut Nurhasan (1986:23). Dalam I Gede Gunawan (2014). Latihan naik tangga dapat juga disebut harvard step, latihan naik turun tangga ini dilakukan bertujuan untuk peningkatan unsur kecepatan dan kekuatan pada kondisi fisik. Sebab unsur kecepatan dan kekuatan merupakan bagian mendasar pada daya tahan. Daya tahan otot adalah kemampuan otot untuk menjalani kontraksi dengan beban submaksimal secara berulang atau mempertahankan kontraksi otot dalam periode waktu tertentu. Jika kamu memiliki daya tahan otot yang baik maka kamu bisa melakukan keiatan yang lama tanpa mengalami kelelahan, tetapi sebaliknya jika kamu tidak memiliki daya tahan yang baik maka kamu mudah mengalami kelelahan. Daya tahan seseorang bisa terus ditingkatkan melalui latihan naik turun tangga, latihan naik turun tangga ini bertujuan untuk meningkatkan daya tahan otot tungkai.

\section{METODE}

Metode penelitian yang digunakan dalam penelitian ini adalah penelitian yang berbetuk kuantitatif yang berbentuk Quasi 
eksperimental design. Quasi eksperimen adalah eksperimen yang memiliki perlakuan (treatments), pengukuran-pengukuran dampak (outcome measures), dan unit-unit eksperimen (eksperimental units) namun tidak menggunakan secara acak. Pada penelitian lapangan biasanya menggunakan rancangan eksperimen semu. Sugiyono (2011:77).

Penelitian eksperimental semu bertujuan untuk memperoleh informasi yang merupakan perkiraan bagi informasi yang dapat diperoleh dengan eksperimen yang sebenarnya dalam keadaan yang tidak memungkinkan untuk mengontrol atau memanipulasi semua variabel yang relevan. Peneliti harus mengerti dengan jelas kompromi-kompromi apa yang ada pada validitas internal. Rancangannya dan berbuat dengan keterbatasan-keterbatasan tersebut. Narbuko,Ahmadi, (2007:54).

Dijelaskan juga dalam Awal Isgiyanto (2009:4), Populasi adalah semua nilai yang mungkin, baik hasil menghitung atau mengukur, Kuantitatif atau Kualitatif mengenai karakteristik tertentu dari semua elemen himpunan data yang ingin di teliti sifat-sifatnya. Populasi harus didenifisikan dengan jelas, dan objek yang menjadi sasaran penelitian harus dijelaskan secara specifik.

Populasi adalah wilayah generalisasi yang terdiri atas: objek atau subjek yang mempunyai kualitas dan karayeristik tertentu yang ditetapkan oleh peneliti untuk dipelajari dan kemudian dan ditarik kesimpulannya. Sugiyono (2011:80). Populasi pada penelitian ini adalah siswa kelas Va dan Vd SDN 69 Kota Bengkulu yang berjumlah 70 orang.

Sampel adalah bagian dari jumlah dan karakteristik yang dimiliki oleh populasi tersebut. Sampel yang diambil menggunakan teknik random sampling (sampel acak) dimana menentukan sampel dengan teknik acak tanpa membedakan jenis kelamin atau hal apapun, apabila terpilih dengan cara diundi.

Pada penelitian ini menggunakan teknik simple random sampling. Dikatakan simpel (sederhana) karena pengambilan anggota sampel dari populasi dilakukan secara acak tanpa memperhatikan starata yang ada dalam populasi itu.

Karena populasi besar, dan peneliti tidak mungkin mempelajari semua yang ada pada populasi, misalnya keterbatasan dana, tenaga dan waktu, maka peneliti dapat menggunakan sampel yang diambil dari populasi itu. Menurut Winarno dalam Cholid Narbuko dan Abu Achmadi (2007:110), “apabila populasi cukup homogen (serba sama), terhadap populasi di bawah 100 dapat dipergunakan sampel $50 \%$, di atas 1000 sebesar 15\%". Memang sebaiknya pupulasi itu lebih banyak daripada sedikit atau kurang.

Apa yang dipelajari dari sampel itu, kesimpulannnya akan dapat diberlakukan untuk populasi. Untuk itu sampel yang diambil dalam penelitian ini adalah 20 orang dari kelas Va dan kelas Vd 20 orang, dengan cara diundi untuk mewakili setiap kelasnya, jadi jumlah sampel yang diambil berjumlah 40 orang siswa kelas V SDN 69 Kota Bengkulu.

\section{Teknik Analisis Data}

\section{Uji Normalitas}

Uji normalitas data dilakukan untuk mengetahui kenormalan data atau data berada dalam keadaan normal. Uji Normalitas data dalam penelitian ini menggunakan metode Lillieforse dan Sudjana ( 1996 : 466 ), dalam skripsi (Romei Hadi, 2010:39). Untuk mengetahui apakah populasi penelitian ini normal atau tidak. Adapun prosedur uji Normalitas tersebut adalah sebagai berikut: dengan menggunakan rumus : 


\section{Uji Homogenitas}

$$
Z_{i}=\frac{\mathrm{X}_{1}-\overline{\mathrm{X}}}{\mathrm{S}}
$$

Untuk mencari atau menguji homogenitas data, digunakan rumus dari Sudjana ( 1996 : 386 ) dalam Romei Hadi (2010:39). sebagai berikut.

\section{Uji Perbedaan}

$$
\mathrm{F}_{\mathrm{dbvb}: \mathrm{dbvk}}=\frac{S D_{b s}^{s}}{S D_{k l}^{2}}
$$

Dijelaskan Sutrisno Hadi (1989 : 278) dalam Romei Hadi (2010). Untuk menghitung perbedaan latihan naik turun tangga tunggal dengan naik turun tangga jamak menggunakan rumus t- test yang digunakan dalam Eksperimen-eksperimen yang menggunakan sampel-sampel yang sudah disamakan salah satu variabelnya. Rumus t- test yang digunakan adalah sebagai berikut:

$$
\begin{aligned}
\mathrm{t} & =\frac{\bar{X}_{1}-\bar{X}_{2}}{s \sqrt{\frac{1}{N_{1}}}+\frac{1}{N_{2}}} \\
\mathrm{~S}_{1} & =\frac{\left(n_{1}-1\right) \mathrm{S}_{1}^{2}+\left(\mathrm{n}_{1}-1\right) \mathrm{S}_{2}^{2}}{\mathrm{n}_{1}+\mathrm{n}_{2}-2}
\end{aligned}
$$

Peningkatan persentase dari latihan yang telah dilakukan, dicari dengan cara sebagi berikut :

$$
\text { peningkatan prosentasi }
$$

$$
=\frac{M d}{\text { Mpre }- \text { tes }} \times 100 \%
$$

keterangan :

Md : perbedaan dari rata-rata test akhir dikurangi test awal

$M$ pre- tes : rata-rata tes awaL

\section{HASIL DAN PEMBAHASAN}

\section{Hasil}

Untuk mencapai tujuan penelitian yang berjudul perbedaan latihan naik turun tangga tunggal (satu tangga) dengan naik turun tangga jamak (enam tangga) terhadap kemampuan lari sprint 60 meter Siswa kelas V SD Negeri 69 Kota Bengkulu, maka peneliti melakukan pengumpulan data. Data yang diperoleh merupakan hasil tes kemampuan lari sprint 60 meter.

Hasil analisis tersebut dapat di interprestasikan sebagai hasil pengujian hipotesis, yaitu : (1) Pengujian hipotesis pertama, terdapat perbedaan antara hasil latihan naik turun tangga tunggal ( satu tangga) dengan latihan naik turun tangga jamak (enam tangga) terhadap kemampuan lari sprint 60 meter Siswa kelas V SD Negeri 69 Kota Bengkulu. Perhitungan dengan $t_{\text {tes }}$ untuk mengetahui perbedaan dari masingmasing kelompok latihan naik turun tangga tunggal diperoleh hasil $t_{\text {hitung }}=2,328>$ $t_{\text {tabel }}$ dengan taraf signifikan sebesar 0,05 adalah 2,101. Melihat harga $t_{\text {hitung }}>t_{\text {tabel }}$ maka dapat disimpulkan bahawa latihan dengan menggunakan metode latihan naik turun tangga tunggal (satu tangga) memberikan perbedaan yang signifikan terhadap kemampuan lari sprint 60 meter Siswa kelas V SD Negeri 69 Kota Bengkulu. Sedangkan kelompok latihan naik turun tanga jamak (enam tangga) diperoleh hasil $t_{\text {hitung }}=2,506>t_{\text {tabel }}$ dengan taraf signifikan sebesar 0,05 adalah 2,101. Hasil $t_{\text {hitung }}>t_{\text {tabel }}$ maka dapat disimpulkan bahwa latihan dengan menggunakan metode latihan naik turun tangga jamak (enam tangga) memberikan perbedaan yang signifikan terhadap kemampuan lari sprint 60 meter Siswa kelas V SD Negeri 69 Kota Bengkulu. Hipotesis yang menyatakan "terdapat perbedaan antara latihan naik turun tangga tunggal (satu tangga) dengan latihan naik turun tangga jamak (enam tangga) terhadap kemampuan lari sprint 60 meter Siswa kelas V SD Negeri 69 Kota Bengkulu". (2) Latihan naik turun tangga jamak (enam tangga) memberikan peningkatan yang lebih signifikan dari pada latihan naik turun tangga tunggal (satu tangga) terhadap peningkatan kemampuan lari sprint 60 meter Siswa kelas V SD Negeri 
69 Kota Bengkulu. Hasil tes akhir pada kedua kelompok latihan ternyata ada perbedaan, dengan taraf signifikan 5\% diperoleh $t_{\text {tabel }} 2,101$. Dengan demikian dapat disimpulkan bahwa $t_{\text {hitung }}=22,78>$ $t_{\text {tabel }}=2,101$. Untuk mengetahui latihan yang lebih baik dianalisis dari peningkatan pre-test dan post-test masing-masing kelompok eksperimen.

\section{Pembahasan}

Data awal diambil dari hasil lari sprint siswa, kemudian di bagi menjadi dua kelompok. Kelompok yang pertama dengan nilai maksimal 18,25 dan nilai minimal 8,45. Nilai kelompok yang kedua 18,21 dan nilai minimal 9,05. Kelompok yang pertama diberikan perlakuan latihan naik turun tangga tunggal (satu tangga) selama lima minggu dengan 15 kali pertemuan. Kelompok yang kedua diberikan perlakuan latihan naik turun tangga jamak (enam tangga) dengan waktu yang sama. Kemudian setelah latihan selam lima minggu siswa melakukan test akhir lari sprint untuk menentukan perbedaan kecepatan latihan lari sprint.

Data hasil tes awal dan tes akhir dihitung menggunakan rumus normalitas, homogenitas. Setalah mendapatkan hasil data yang normal dan homogen data kemudian dihitung uji perbedaan dan mendapatkan perbedaan yang signifikan sebesar 2,278. Dengan

Kelebihan latihan naik turun tangga jamak dibandingkan naik turun tangga tunggal adalah bisa mengatur pernapasan yaitu ketika naik tangga dengan cepat dan ketika turun tangga bisa mengatur pernapasan, dapat meningkatkan kekuatan otot karena tangga yang harus dilewati lebih dari satu tangga, meningkatkan daya kecepatan dengan cara naik dan turun tangga berulang. Karena dengan bisa mengatur pernapasan serta meningkatnya kekuatan dan kecepatan maka lari sprint 60 meter siswa akan meningkat di bandingkan dengan latihan naik turun tangga tunggal (satu tangga). Sesuai dengan pendapat Nurhasan (1986:23) Latihan naik turun tangga ini dilakukan bertujuan untuk peningkatan unsur kecepatan dan kekuatan pada kondisi fisik. Sebab unsur kecepatan dan kekuatan merupakan bagian mendasar pada daya tahan.

\section{PENUTUP}

\section{Simpulan}

Berdasarkan hasil penelitian dan pembahasan yang telah diuraikan pada bab terdahulu dapat dikemukakan kesimpulan sebagai berikut, diketahui bahwa nilai ratarata kelompok ekspremen 1 adalah 10,42 detik dan nilai rata-rata eksperiemen 2 yaitu 10,24 detik. Kemudian data dilanjutkan dengan uji prasyarat statitik statis semua data hasil penelitian berdistribusi normal dengan masing-masing varians berdistribusi homogen. Uji hipotesis penelitian diperoleh t hitung sebesar 2,278 dan t tabel 2,101 dengan taraf pengujian $\alpha 5 \%$ maka hipotesis diperoleh "latihan naik turun tangga jamak (enam tangga) lebih baik dibandingkan latihan naik turun tangga tunggal (satu tangga)" di terima. Maka penelitian ini dapat disimpulkan latihan mana yang lebih baik, Bahwa latihan naik turun tangga jamak (enam tangga) lebih baik dibandingkan dari pada metode latihan naik turun tangga tunggal (satu tangga) terhadap kemampuan lari sprint siswa 60 meter kelas V SD Negeri 69 Kota Bengkulu.

\section{Saran}

Berdasarkan hasil kesimpulan diatas maka peneliti dapat memberikan saran yang dapat membantu mengatasi masalah yang ditemui dalam pencapaian lari sprint 60 meter dalam olahraga atletik yaitu : (1) Berdasarkan hasil penelitian ini dapat disarankan pada guru olahraga khusunya pada lari sprint untuk dapat meningkatkan kemampuan lari sprint siswa guru bisa 
menggunakan latihan naik turun tangga jamak. (2) Setiap melakukan pembelajaran olahraga khususnya lari sprint diharapkan menggunakan lapangan yang datar dan luas sehingga anak-anak bisa lari sprint dengan maksimal. (3) Untuk siswa sebaiknya menggunakan latihan naik turun tangga jamak (enam tangga) untuk meningkatkan kecepatan lari sprint 60 meter.

\section{DAFTAR PUSTAKA}

Dian Anggraeni (2013). Pengaruh Latihan Naik Turun Bangku Dan Naik Turun Tangga Terhadap Peningkatan Kebugaran Jasmani. Universitas Lampung

Ahmadi, Narbuko. (2007). Metodologi penelitian. Jakarta: Bumi Aksara.

Awal, Isgiyanto. (2009). Teknik Pengambilan Sampel. Jogjakarta:Mitra Cendika.

I Gede Gunawan. (2014). Pengaruh Naik Turun Bangku Dan Tangga Terhadap Keterampilan Renang Gaya Bebas. Universitas Lampung.

Nanang Budianto (2012). Perbedaan Kemampuan Lari 40 M Siswa Sekolah Dasar Di Daerah Perkotaan Dengan Siswa Sekolah Dasar Didaerah pegunungan. Universitas Negari Yogyakarta.

Saputra. Y. M (2011). Dasar-dasar keterampilan atletik. Jakarta: Direktorat Jenderal Olahraga

Sugiyono. (2011). Metode penelitian Kuantitatif,kualitatif dan $R$ dan $D$. Bandung : Alfabeta 